\title{
BOVINE PAPILLOMAVIRUS TYPE 2 IN REPRODUCTIVE TRACT AND GAMETES OF SLAUGHTERED BOVINE FEMALES
}

\author{
Claudemir de Carvalho ${ }^{1,2,3 *}$; Antonio Carlos de Freitas ${ }^{1,2}$; Olga Brunner ${ }^{1}$; Luiz Gustavo Bentim Góes ${ }^{1}$; \\ Andréa Yaguiu Cavalcante ${ }^{1}$; Willy Beçak ${ }^{1,2}$; Rita de Cassia Stocco dos Santos ${ }^{1,2}$. \\ ${ }^{1}$ Laboratório de Genética, Instituto Butantan, São Paulo, SP, Brasil. ${ }^{2}$ Universidade de Taubaté, Taubaté, SP, Brasil. \\ ${ }^{3}$ Faculdade de Pindamonhangaba, Pindamonhangaba, SP, Brasil.
}

This paper corresponds to an "extended abstract" selected for oral presentation in the $22^{\text {nd }}$ Brazilian Congress of Microbiology, held in Florianópolis, SC, Brazil, in November 17-20, 2003

\begin{abstract}
Papillomaviruses are described selectively infecting epithelial tissues and are associated with many forms of cancer in different species. Considering the widespread dissemination of papillomatosis in livestock, interest is being centred on possible forms of viral transmission and respective mechanisms. In the present study, we report the detection of bovine papillomavirus (BPV) DNA sequences in female reproductive tract tissues, fluids and oocytes from slaughtered bovines not afflicted by cutaneous papillomatosis. BPV-2 DNA sequences were found in ovarian and uterine tissues as well as in oocytes, cumulus cells and uterine flushings. The presence of papillomavirus sequences in reproductive organ tissues and fluids shows that viral infection in organisms can be verified in others tissues, not only in epithelial ones. The present findings alert to the possibility of BPV transmission in embryo transfer programs and assisted fertilization procedures.
\end{abstract}

Key words: BPV-2, papillomatosis, gametes, PCR.

\section{INTRODUCTION}

The development of techniques applied to the bovine reproduction resulted in the necessity of control of the diseases of the reproductive tract, mainly infectious agents. It has been discussed about the possibility of transmission of these agents by embryo transfer $(1,2,3)$. Yet, there are no data about papillomaviruses detection in tissues of bovine female reproductive tract and gametes. Bovine papillomaviruses are a small group of 6 different double strand DNA viruses that can infect fibroblasts and queratinocytes (types 1,2 and 5) and epithelial cells (types 3,4 and 6) (4). BPV-2 induces fibropapillomas in the head and neck of animals and is associated to natural lesions of the urinary bladder, although it may occasionally be related to fibropapillomas in the oesophagus and rumen (4). The bovine papillomatosis causes economic losses spread in dairy farms in Brazil (5). The fact associated to the increased use of embryo transfer and in vitro fertilization techniques demands accurate studies to evaluate the presence of bovine papillomavirus in the female reproductive tract and gametes which is the aim of the present report. The viral type selected for this evaluation was BPV-2 due to its enlarged frequency in our previous data.

\section{MATERIALS AND METHODS}

We selected animals from Vale do Paraíba-SP, Brazil to confirm the high incidence of BPV-2 and eventual presence in the reproductive tract. We selected 3 bovine females (Bos taurus taurus) afflicted by cutaneous warts and proceeded the uterine flushing with a saline buffer (PBS) and surgical removal of wart samples. About $25 \mathrm{mg}$ of tissue and $200^{1 / 41}$ of flushing fluid were

*Corresponding author. Mailing address: Laboratório de Genética, Instituto Butantan. Av. Vital Brazil, 1500, Butantã. 05503-900, São Paulo, SP, Brasil. E-mail: acdefreitas@butantan.gov.brou claudemirdec@yahoo.com.br 
used for DNA extraction by Quiagen columns according to respective protocol. About 300ng of the extracted DNA were then used for PCR analysis with specifical primers to BPV-2 (Fw: 5'-GTTATACCACCCAAAGAAGACCCT - 3'; Rev.: 5' CTGGTTGCAACAGCTCTCTTTCTC-3'). PCR protocol was developed according to Stocco dos Santos et al. (6). After detection of BPV-2 sequences in the analysed samples, confirming the presence of papillomavirus in uterine environment, we collected the ovaries and segments of the uterus of 2 slaughtered females (Bos taurus taurus) not showing cutaneous warts. These animals came from a herd with a high incidence of papillomatosis. The ovarium follicles were aspirated to pick up the oocytes and then the oocytes were separated from cumulus cells by pipetting. DNA extraction from ovaries, uterine samples, oocytes and their respective cumulus was performed as previously described for warts and uterine flushings. PCR was made in the same conditions using the same specifical primers to BPV-2 and primers to bovine $\beta$-globin (Fw: 5' -AACCTCTTTGTTCACAACCAG-3'; Rev: 5' CAGATGCTTAACCCACTGAGC-3') to evaluate the DNA conditions for PCR. Confirmation of PCR results was obtained by southern blot using BPV-2 genome as probe.

\section{RESULTS}

The method described was efficient to detect BPV-2 DNA in the samples investigated as showed in Fig. 1A and 1B. One of the 2 slaughtered females did not show positive detection of BPV-2 in the uterus and ovaries samples.

\section{DISCUSSION}

In this study we report the presence of papillomavirus in the reproductive tract and gametes of bovine females. Although the vast literature concerning the contamination of the uterus and gametes of bovines by viruses as bluetongue virus (BTV), bovine leukaemia (BLV) and virus of the bovine viral diarrhea (BVDV) $(7,8,9)$, this is the first report describing the presence of papillomavirus in these tissues and cells. Vanroose et al. (10) suggested that the viruses can get the oocytes trough granulosa and cumulus cells although they have not discussed how the viruses can reach these cells. Stocco dos Santos et al. (6) demonstrated the presence of papillomavirus in the blood of naturally infected animals. The presence of viruses in the bloodstream, theoretically allows them to be carried to any irrigated tissues. This possibility could explain the presence of BPV-2 in the ovaries, uterus, cumulus and oocytes of the investigated animals. Papillomaviruses are discussed as epitheliotropic (4) but the presence of DNA of papillomavirus in reproductive organ tissues, fluids and gametes indicates that viral infection could not be so specific. Many authors have been discussed the possibility of transmission of infectious agents by embryo transfer

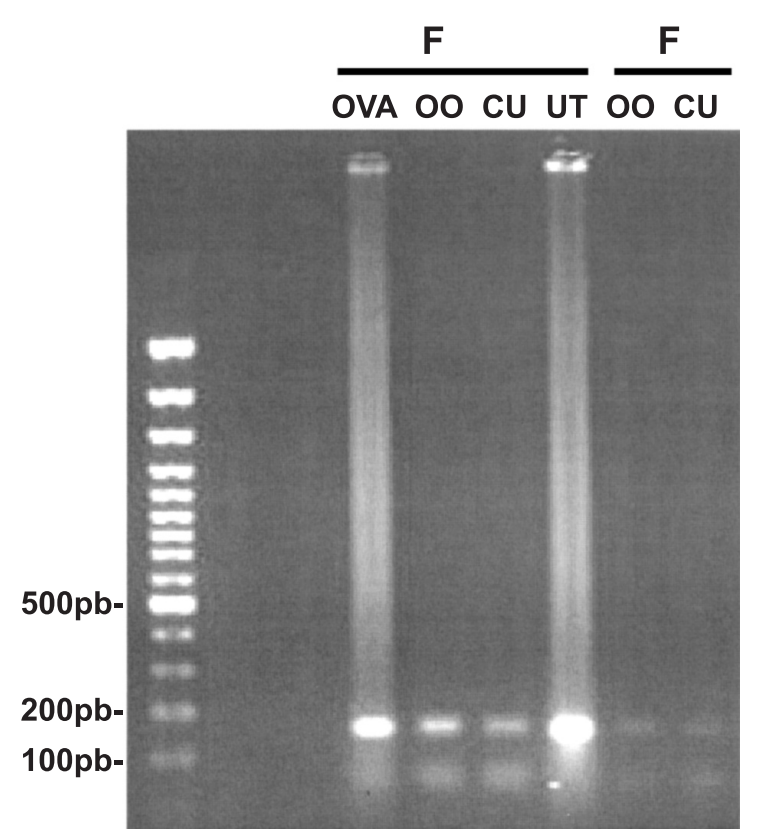

Figure 1A. BPV-2 DNA sequences detected in the samples of ovaries (OVA), uterus (UT), oocytes (OO) and cumulus (CU) from one of the two slaughtered cows and samples of oocytes (OO) and cumulus (CU) from the other female.

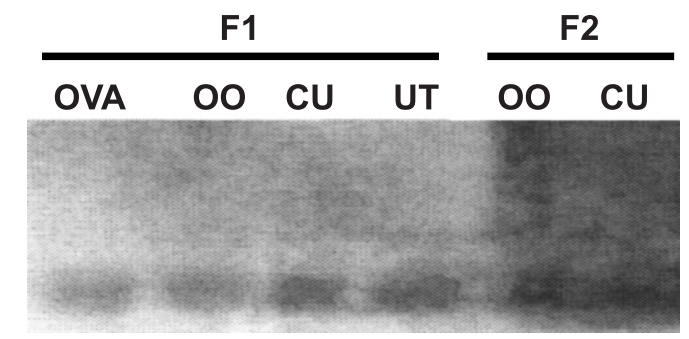

Figure 1B. Confirmation of the results by southern blot with specific probes to BPV-2.

and in vitro fertilization procedures and the indispensable control of the cells related to the procedures $(1,2,3,11)$. Our data emphasise the need to include papillomaviruses as important agents to be investigated in reproduction procedures with rigorous control of uterine environment of embryo donors, recipients and oocytes collected from slaughtered animals.

\section{RESUMO}

\section{Detecção de papilomavírus bovino tipo $2 \mathrm{em}$ trato reprodutivo e gametas de fêmeas bovinas}

Os vírus do papiloma bovino, descritos como agentes infectantes específicos do epitélio, têm sido associados a 
diversas formas de câncer em diferentes espécies animais. Dada a intensa disseminação da papilomatose nos rebanhos, a investigação de diferentes formas de transmissão e seus respectivos mecanismos tem exigido especial atenção. No presente estudo, é relatada a detecção de seqüências genômicas do papilomavirus bovino (BPV) em ovócitos e tecidos do trato reprodutivo oriundos de fêmeas abatidas comercialmente, não apresentando papilomatose cutânea. A presença de DNA de BPV-2 em tecidos do trato reprodutivo, lavado uterino, ovócitos e células do cumulus traz evidências de que a infecção viral pode se desenvolver fora do tecido epitelial. Esses achados alertam para a possibilidade de transmissão do BPV através dos procedimentos de transferência de embriões e de fertilização in vitro.

Palavras-chave: BPV-2, papilomatose, gametas, PCR.

\section{REFERENCES}

1. Eaglesome, M.D.; Hare, W.C.D.; Singh, E.L. Embryo transfer: a discussion on its potential for infectious disease control based on a review of studies on infection of gametes and early embryos by various agents. Cancer Veter. J., 21:106-112, 1980.
2. Le Tallec, B.; Ponsart, C.; Marquant-Le Guienne, B.; Guérin, B. Risks of transmissible diseases in relation to embryo transfer. Reprod. Nutr. Dev., 45(5):439-450, 2001.

3. Stringfellow, D.A.; Givens, M.D. Infectious agents in bovine embryo production: hazards and solutions. Theriogenology, 53:85-94, 2000.

4. Campo, M. S. Animal model of papillomavirus pathogenesis. Virus Res., 89:249-261, 2002.

5. Lindsey, C.J.; Stocco dos Santos, R.C.; Freitas, A.C.; Carvalho, C.; Beçak, W. Vírus do papiloma: vias de transmissão, risco oncogênico e co-fatores ambientais. Laes e Haes, 2003. In press.

6. Stocco dos Santos, R.C.; Lindsey, C.J.; Ferraz, O.P.; Pinto, J.R.; Mirandola, R.S.; Benesi, F.J.; Birgel, E.H.; Pereira, C.A.B.; Beçak, W. Bovine papillomavirus transmission and chromosomal aberrations: an experimental model. J. Gen. Virol., 79:2127-2135, 1998.

7. Bielanski, A.; Sapp, T.; Lutze-Wallace, C. Association of bovine embryos produced by in vitro fertilization with a noncytopathic strain of bovine viral diarrhea virus type II. Theriogenology, 49:1231-1238, 1998.

8. Tsuboi, T.; Kanazawa, Y.; Syoji, T.; Tokuhisa, S. Growth activity of bovine herpesvirus 1 in bovine follicular oocytes with cumulus cells. J. Vet. Med. Sci., 54(6):1179-1181, 1992.

9. Tsuboi, T.; Imada, T. Detection of BVDV in bovine embryos derived from persistently infected heifers by PCR. Vet. Rec., 142:114-115, 1998.

10. Vanroose, G.; de Kruif, A.; Van Soom, A. Embryonic mortality and embryo-pathogen interactions. Anim. Reprod. Sci., 60(61):131$143,2000$.

11. Wrathall, A.E. Embryo transfer and disease transmission in livestock: a review of recent researchs. Theriogenology, 43(1):81-88, 1995. 